\title{
Abnormal behaviors mediated by nest cell size: a case study with Yemeni honey bees
}

\author{
Hossam F. Abou-Shaara \\ Baqshan`s Chair for Bee Research, Plant Protection Department, College of Food and \\ Agriculture Sciences, King Saud University, P.O.Box. 2460, Riyadh 11451, \\ Saudi Arabia.email: entomology_20802000@yahoo.com
}

\section{ABSTRACT}

In the Yemeni honey bee, Apis mellifera jementica, as in other species of honey bees in the genus Apis, the queen is responsible for the egg-laying duties, while workers are facultatively sterile and perform other colony-wide tasks. Under certain conditions, however, workers can lay unfertilized eggs that develop into male drones. In this study, the effect of cell size on queen egg laying and worker policing behaviorswas investigated. Yemeni honey bee queens were allowed to lay eggs in different cell size combs. Abnormal queen-laid eggs in large cell size combs were found to be removed by workers firstly followed by worker-laid eggs within 24 hours while abnormal queen-laid eggs, in normal cell size combs, survived up to three days. Nest cell size seemed to contribute in the alteration of queen egg laying and policing behaviors.

Keywords: Apis mellifera/ honey bee queen/ cell size/ worker policing/ egg-laying.

\section{INTRODUCTION}

Honey bees in the genus Apis are monogynous, that is, reproduction is monopolized by one single queen, while the rest of the colony-wide tasks are performed by facultively sterile workers. Under certain special situations, however, a proportion of the workerforce may activate their ovaries and start laying unfertilized eggs regardless of the queen presence under uncommon behavioral mutations (Oldroyd et al., 1994). Under normal circumstances, the queen lays one egg per cell and the queen-laid eggs are at the center of the hexagonal cell bottom. In general, honey bee workers can discriminate between worker-laid eggs and queen-laid eggs (Oldroyd and Ratnieks, 2000 and Nanork et al., 2007), and the removal of worker-laid eggs by other workers is known as worker policing (e.g. Ratnieks and Visscher). Also, in honey bee colonies there are two nest cell sizes for rearing brood; a small one for workers and slightly larger one for drones.

Relatively little studies have been done on the role of cell sizes in honey bee colonies, for example, a correlation between brood cell size and bee morphology has been found (Ruttner, 1988 and McMullan and Brown, 2006) and also with varroa mite infestation (Issa et al., 1993; Piccirillo and De Jong, 2003 and Berry et al., 2010).Moreover, the age of the combs has been found to impact brood production (Berry and Delaplane, 2001) while the cells width has an impact on honey production (Seeley, 2002). The wax cells size (width) of honey bee combs is not stable for honey bee subspecies (Piccirillo and Jong, 2003) as well as within the same colony combs(Piccirillo and De Jong, 2004). Unfortunately, there areno available literatures addressed the possible role of nest cell size in egg laying behavior of honey bee queens and policing behavior by workers. Therefore, this research was conducted to 
study the impacts of nest cell size on egg-laying and policingbehaviors.

\section{MATERIALS AND METHODS}

All experiments were performed at the apiary of the Bee Research Unit, King Saud University. Combs with two different types of wax cell size were used; one from Yemeni honey bee colonies, small bees, with cell size mean \pm SE $(4.29 \pm 0.13 \mathrm{~mm})$ and the other from Carniolan honey bee colonies, large bees (Fig.1), and from honey storing area with cell size mean $\pm \operatorname{SE}(5.37 \pm 0.02 \mathrm{~mm})$. The difference between the two cell types was about $1.08 \mathrm{~mm}$ and the large cell size was larger than drone cell size of Yemeni honey bees by about $0.3 \mathrm{~mm}$. The measurements of cell size were taken according to the method of McMullan and Brown (2006).

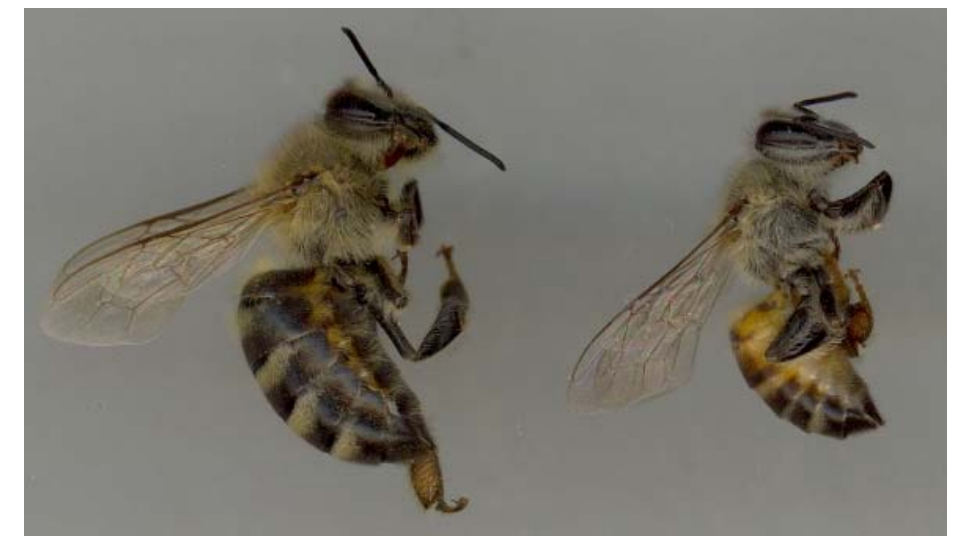

Fig.1: Carniolan honey bee worker (left) and Yemeni honey bee worker (right).

The following experiments were performed on five frame colonies, headed with about one year old Yemeni honey bee queens, to test the role of cell size in egg laying and policing behaviors.

\section{1- Abnormal queen-laid eggs at different cell size.}

Exp.1: Large cell size/under caging conditions. Fivequeens were confined under cages $(10 \times 10 \mathrm{~cm})$ with a queen excluder material up to 4.5 hours on large cell size wax combs then the number of laid eggs was counted.

Exp.2: Large cell size/ without caging. Honey bee queens were forced to lay eggs in large cell size combs without caging by using evacuation method where five honey bee colonies were evacuated from all combs. Then only one comb with large cells size was added to each colony. It was hypothesized that the existence of one comb could be the only choice for the queen to lay large number of eggs in short time as the colony could be under the force of reconstruction.Subsequently, the number of laid eggs was counted after 2.5 hours.

Exp.3: Normal cell size/ under caging conditions. Five queens were confined under (10 x $10 \mathrm{~cm}$ cages) with queen excluder part on normal cell size combs up to 24 hours to obtain sufficient number of eggs. The number of normal queen-laid eggs, one egg per cell and at the bottom, was counted.

\section{2- Policing behavior.}

I: Queen-laid eggs/large cell size. The number of queen-laid eggs of Exp.1 was counted and, after removing the cages, re-examined daily to count the number of removed eggs(to identify egg removal behavior).

II: Queen-laid eggs and worker-laid eggs /normal cell size. The number of queenlaid eggs in Exp.3 was recorded and re-examined daily to count the number of 
removed eggs (policing behavior against queen-laid eggs). To study policing behavior against worker-laid eggs, combs with worker-laid eggs from queenless colony, were placed into four colonies of Exp.3(one comb per colony). The number of worker-laid eggs was counted before placing the combs and re-counted daily to count the number of removed eggs (policing behavior against worker-laid eggs).

During the above-mentioned experiments combs examination was done under light source and with the help of binocular. Egg imageswere taken by using a camera equipped to the computer at $40 \mathrm{x}$ magnification.During the above mentioned experiments queens were allowed to lay eggs at different times ranged from 2.5 to 24 hours and that was based on the experimental conditions and field observations, under caging conditions it was expected that more eggs can be laid in short time while without caging queens may need a relatively long time to lay a sufficient amount of eggs.

\section{RESULTS}

\section{1- Abnormal queen-laid eggs at different cell size.}

Exp.1: Large cell size/ under caging conditions.queens laid some eggs ranged from 0 to 15 with mean \pm SE of7.60 \pm 2.50 eggs. The laid eggs were not at the bottom of the cells and not toward the center, instead some eggs were laid at the cell walls or at the upper end of the cell wall in an arbitrary manner. Moreover, some cellscontained more than one egg in a behavior somewhat similar to false queens. The mean $\pm \mathrm{SE}$ of normal eggs, one egg per cell at the bottom center, was $4 \pm 1.58$ eggs.

Exp.2: Large cell size/ without caging. queens laid some eggs ranged from 5 to 16 eggs at the both sides of the comb with mean \pm SE of $9.20 \pm 1.98$ eggs. The laid eggs were also abnormal where some eggs were laid at the cell wall and some cells contained more than one eggas in Fig.2. Normal eggs mean \pm SEwas $6 \pm 1.22$ eggs.
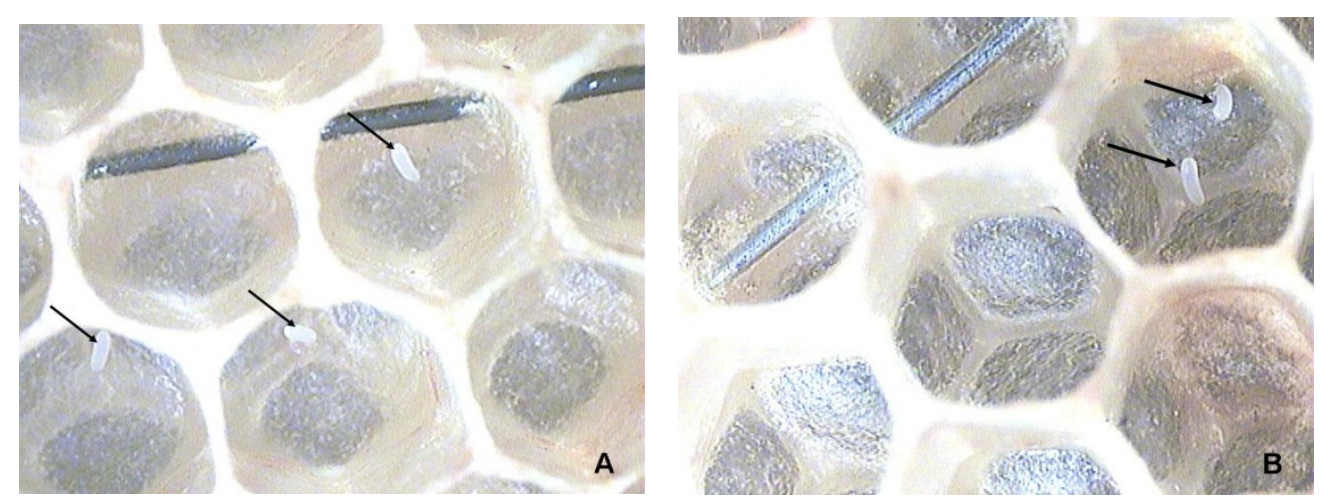

Fig. 2: Abnormal egg laying behavior into large cell size. Random eggs (A) and more than one egg inside the single cell (B).

Exp.3: Normal cell size/ under caging conditions. Queens laid a large number of eggs with mean \pm SE of136.6 \pm 17 .16eggs and more than one egg inside some cells while other cells were left without laying any eggs. The mean \pm SE of normal eggs was $132 \pm 17.00$ eggs. It was clear that under caging conditions queens can lay more than one egg inside single cell even if they were confined on their natural cell size, that may be due to the long period of caging and the small available area for laying eggs. 


\section{2- Policing behavior.}

I: Queen-laid eggs/large cell size.After about 24 hours no eggs werefound where workers completely removed all the laid eggs.

II: Queen-laid eggs and worker-laid eggs /normal cell size. Workers did not remove queen-laid eggs immediately but they removed them after 72 hours. On the other hand, worker-laid eggs with mean \pm SE of87.18 $\pm 7.90 \%$ were removed after 24 hours and all eggs were removed withinthree days. It was clear that three different egg removalcases were found; $1^{\text {st: }}$ queen-laid eggs, into large cell size, were removed completely within 24 hours, $2^{\text {nd }}$ : most of worker-laid eggs were removed within 24 hours and $3^{\text {rd. }}$ : extra queen-laid eggs, in normal cell size, were not removed within 24 , 48 and about 72 hours. These cases depict the confusing in the policing behavior.

\section{DISCUSSION}

Unlike queens of other honey bee subspecies, Yemeni honey bee queens seemed to respond slowly for new colony conditions and therefore Yemeni queens laid a little number of eggs. It seemed that honey bee individuals have a preference for a certain nest cell size. In a previous study was done by McMullan and Brown (2006) found no problem in rearing brood when honey bee (A. m. mellifera) colonies were provided with combs with cell size less than their own by $0.5 \mathrm{~mm}$ but the emerged bees were relatively small.The contrast was done in this study, the wax cell size was larger than the natural cells by about $1 \mathrm{~mm}$ and such large size maybe not suitable for the gyne. In general colony individuals maybe prefer certain nest cell size, similar to their own or less, over the large one.

Concerning egg laying behavior, queens laid some abnormal eggs in a behavior somewhat similar to false queens when they were forced to lay eggs with or without caging into the large cell size combs. Perhaps the reason for such behavior is the large cell sizewhich madequeens unable to completely control egg laying process to fix their eggs at the cell bottom and toward the center. Thus the queen was not sure from laying the egg and laid more than one egg. Also, the queen-laid eggs were removed within 24 hours by workers when combs were left in the colonies. It is known that workers can discriminate between queen-laid eggs and worker-laid eggs due to the presence of chemical signal (Oldroyd and Ratnieks, 2000) which exist only in queenlaid eggs. Worker-laid eggs were found to be eaten by police workers even if it was treated with some chemicals like hydrocarbon (Martin et al., 2002) or synthetic ester (Katzav-Gozanskyet al., 2001).Here eggs were laid by the queen and with the chemical signal. Thus, it is suggested that the worker policing was affected by the large cell size where the police workers realized that such large cells could not be benefit for brood rearing.

Concerning policing behavior, it was clear that there was three different cases in egg removal behavior. The $1^{\text {st }}$ case: queen-laid eggsinto large cell size which were removed completely within 24 hours. The $2^{\text {nd }}$ case: majority of worker-laid eggs was removed within 24 hours. The $3^{\text {rd }}$ case: extra queen-laid eggs in normal cell size were not remove within 24 and about 72 hours. In the first case that maybe because police workers found that large cell size was not a suitable place for queen-laid eggs. In the second case worker-laid eggs were removed by the effective police workers while in the third case perhaps the police workers did not remove the extra laid eggs of the queen due to the presence of the queen chemical signal and being the eggs were laid in a normal cell size. During the experiments some workers were noticed to push their heads inside some normal cells with extra laid eggs but without removingany eggs. 
Such conundrum in policing behavior reflects their sensitivity to nest cell sizes. Results here give an important explanation to the abnormal egg laying behavior of honey bee queens due to the nest cell size. Wax cell size can mediate the queen egg laying behavior to be abnormal as well as policing behavior.

\section{ACKNOWLEDGEMENT}

Thanksare given to Deanship of Scientific Research and College of Food and Agriculture Science Research Center as well as Bee Research Unit for providing the necessary materials for the research.

\section{REFERENCES}

Berry, J. A., and Delaplane, K. S. (2001): Effects of comb age on honey bee colony growth and brood survivorship. J. Apic. Res. 40(1):3-8.

Berry, J. A., Owens, W. B., and Delaplane, K. S. (2010): Small-cell comb foundation does not impede Varroa mite population growth in honey bee colonies. Apidologie. 41: 40-44.

Issa, M.R., De Jong, D., and Goncalves, L.S. (1993): Reproductive strategies of the mite varroa jacobsoni (Mesostigmata, Varroidae): Influence of larva type and comb cell size on honey bee brood infestation rates. Rev. Bras. Genet. 16: 219-224.

Katzav-Gozansky, T., Soroker, V., Ibarra, F., Francke, W., and Hefetz, A. (2001): Dufour's gland secretion of the queen honeybee (Apis mellifera): an egg discriminator pheromone or a queen signal?. Behav Ecol Sociobiol. 51:76-86.

Martin, S.J., Jones G.R., Chaline, N., Middleton, H., and Ratnieks, F.L.W. (2002): Reassessing the role of the honeybee (Apis mellifera) Dufour's glands in egg marking. Naturwissenschaften. 89:528-532.

McMullan, J. B., and Brown, M. J.F. (2006): The influence of small-cell brood combs on the morphometry of honeybees (Apis mellifera). Apidologie. 37: 665-672.

Nanork, P., Wongsiri,S., and B. P. Oldroyd. (2007): Preservation and loss of the honey bee (Apis) egg-marking signal across evolutionary time. Behav Ecol Sociobiol. 61: 1509-1514.

Oldroyd, B. P., and Ratnieks, F. L.W. (2000): Evolution of worker sterility in honey-bees (Apis mellifera): how anarchistic workers evade policing by laying eggs that have low removal rates. Behav. Ecol. Sociobiol. 47:268-273.

Oldroyd, B. P., Smolenski, A. J., Cornuet, J. M., and Grozier, R.H. (1994): Anarchy in the beehive. Nature. 371(6500):749.

Piccirillo, G. A., and De Jong, D. (2003): The influence of brood comb cell size on the reproductive behavior of the ectoparasitic mite Varroa destructor in Africanized honey bee colonies. Genetics and Molecular Research. 2 (1): 36-42.

Piccirillo, G. A., and De Jong, D. (2004): Old honey bee brood combs are more infested by the mite Varroa destructor than are new brood combs. Apidologie. 35:359-364.

Ratnieks, F. L. W.and P. K. Visscher (1989): Worker policing in the honeybee. Nature, 342:796 - 797.

Ruttner, F.(1988): Biogeography and taxonomy of honeybees, Springer Verlag, Berlin.

Seeley, T. D. (2002): The effect of drone comb on a honey bee colony's production of honey. Apidologie.33:75-86. 